\title{
Comparative Thermal Performance Study of Indirect and Mixed-mode Solar Dryers
}

\author{
Shobhana Singh and Subodh Kumar \\ Centre for Energy Studies, \\ Indian Institute of Technology, \\ Delhi, India
}

\begin{abstract}
In the present study, simple performance evaluation method of solar dryers is proposed. The methodology based on steady state heat balance concept applied to the absorber surface of collectordryer assembly is proposed for identification of dimensionless parameter called effectiveness of dryer, $\varepsilon$. No-load experiments on mixed-mode and indirect solar dryers have been performed for forced air circulation under indoor controlled conditions. Dryers are tested for a wide range of operating conditions of absorbed thermal energy (300$\left.800 \mathrm{~W} / \mathrm{m}^{2}\right)$ and air mass flow rate $(0.009-0.026 \mathrm{~kg} / \mathrm{s})$. Based on comparison results of computed values of $\varepsilon$ for both of these dryer, it is found that there is significant performance improvement of $48 \%$ in case of mixed-mode in contrast to indirect dryer. The study further reveals that for both dryers there is sharp rise in $\varepsilon$ values when air mass flow rate is increased from 0.009 to $0.017 \mathrm{~kg} / \mathrm{s}$ and thereafter a marginal increase can be noticed when air mass flow rate is enhanced to $0.026 \mathrm{~kg} / \mathrm{s}$. Another important finding of present study relates to invariable $\varepsilon$ values obtained for a wide range of absorbed energy and ambient air temperature data irrespective of air circulation mode adopted for a dryer.
\end{abstract}

Keywords- mixed-mode dryer; indirect dryer; noload indoor test; forced convection; dryer effectiveness

\section{Nomenclature}

A Cross-sectional absorber area $\left(\mathrm{m}^{2}\right)$

$C_{p} \quad$ Specific heat of air $(\mathrm{J} / \mathrm{kgK})$

E Confidence interval

$h_{c f g} \quad$ Convective heat transfer coefficient from hot air to glass cover of collector-dryer assembly $\left(W / m^{2} K\right)$

$h_{c p f} \quad$ Convective heat transfer coefficient from absorber plate to hot air of collector-dryer assembly $\left(W / m^{2} K\right)$

$\dot{m} \quad$ Air mass flow rate $(\mathrm{kg} / \mathrm{s})$

$N \quad$ Number of observations

$S E \quad$ Standard error of mean $\sigma \quad$ Standard deviation

$\bar{T}_{f} \quad$ Average temperature of hot air of collectordryer assembly $\left({ }^{\circ} \mathrm{C}\right)$

$\bar{T}_{f i} \quad$ Average temperature of air at collector inlet $\left({ }^{\circ} \mathrm{C}\right)$

$\bar{T}_{f i} \quad$ Average temperature of air at collector inlet $\left({ }^{\circ} \mathrm{C}\right)$

$\bar{T}_{f o} \quad$ Average temperature of hot air at dryer outlet $\left({ }^{\circ} \mathrm{C}\right)$

$\bar{T}_{g} \quad$ Average temperature of glass cover of collector-dryer assembly $\left({ }^{\circ} \mathrm{C}\right)$

$\bar{T}_{p} \quad$ Average temperature of absorber plate of collector-dryer plate assembly $\left({ }^{\circ} \mathrm{C}\right)$

$T_{a m} \quad$ Temperature of ambient air $\left({ }^{\circ} \mathrm{C}\right)$

$\bar{x} \quad$ Arithmetic mean

$\varepsilon \quad$ Effectiveness of dryer

\section{Introduction}

In present scenario our world is facing two main challenges: one is to meet the exponential growing demand for energy particularly in developing countries and other is to deal with the global, regional and local environmental impacts resulting from supply and use of conventional energy. Renewable energy is a promising answer to the problems for sustaining today's state of civilization. Thus, utilizing the renewable energy resources for development of green technologies need to be fully exploited as it will lead to increased energy availability for future mankind. Solar energy is the primary source of all renewable energy resources. It has enormous potential to meet growing energy requirements of increasing population of the developing world. Its virtually inexhaustible supply with global distribution and environmentally safe nature make solar energy a very attractive prospect worldwide. Improvement in sustainable solar energy technologies to harness the sun's enormous power is therefore required to meet present energy crises.

The cost-effective technology for solar drying that can be easily adopted among the rural farmers of developing countries needs to be developed in the areas where solar energy is available in abundance. The drying process is of special interest in case of fruits and vegetables as they are particularly 
vulnerable to attack by insects. Solar dryers in contrast to open air sun drying are designed to provide food product a controlled exposure to solar radiation which often improves product quality and save considerable drying time.

The construction of solar dryers varies from a simple dryer to a complicated one. Selection of solar dryer for a particular food product is determined by quality requirements, product characteristics and economic factors [1]. Many of the parameters on which drying process depends are (i) outdoor solar radiation (ii) ambient air temperature (iii) relative humidity (iv) size of the product sample being dried (v) dryer system design (vi) airflow patterns within the drying system. Solar energy drying systems can be broadly classified according to their heating modes and manner in which the solar heat is utilized. They can be further categorized into two major groups, namely active and passive solar energy drying systems. Three distinct sub-classes of either the active or passive solar drying systems can be identified as direct, indirect and mixed-mode type solar dryer, depending on design arrangement of system components and mode of solar heat utilization [2].

For more than five decades, the various designs of solar energy drying systems operating on forced mode have been developed and tested for the efficient utilization of solar energy around the world [1-4]. The literature survey indicates that out of several dryer designs developed and studied, the indirect and mixed mode solar dryers have received the maximum attention of researchers for mathematical modeling and thermal performance evaluation.

The thermal test procedure for standardization of various solar energy devices/equipments is necessary to evaluate their performance and provide the equitable basis for comparison among various available designs, thus leading to design improvement by the manufactures. The test procedures for standardization of some solar equipments namely, flat plate solar collector, solar air heaters, solar cookers etc., have already been developed and adopted in many countries, including India for performance evaluation $[5,6]$. Sodha and Chandra [3] reviewed several designs of solar air collector and presented various testing methods for their evaluation, considering them the critical and important component of solar dryers. Similarly, Grupp et al. [7] presented a method of evaluating and comparing solar dryers by conducting tests on various designs of dryers such as a circular box-type dryer, a shell dryer, a cabinet dryer, a tunnel dryer and chimney dryer. On the basis of tests, an overall grading was awarded to the tested dryer. Jannot and Coulibaly [8] proposed the term of evaporative index for rating the performance of the solar air heater connected in series with a solar drying chamber.
Recently, Leon et al. [1] presented a more detailed review of testing procedures, very often used for reporting thermal performance evaluation results. The literature review indicates that most of the researchers [9-12] considered the drying efficiency as an important parameter to evaluate the thermal performance of solar dryer as a alone or integrated with air collector. The major factors affecting this parameter include air temperature rise in drying chamber/food product, air flow rate, collector/dryer design etc. In fact, food product shape, size and composition also significantly influence this parameter.

The literature review indicates that thermal tests on solar dryers with and without load have been reported identifying two performance parameters namely-overall heat loss coefficient, $U_{L}$ and drying efficiency, $\eta_{d}$ respectively. The determination of $U_{L}$ is based on the maximum temperature of various components such as plate, glass cover, fluid etc., attained inside the dryer under stagnation condition $[13,14]$. On the other hand, the drying efficiency, $\eta_{d}$ is determined as the ratio of amount of water evaporated to incident solar radiation intensity for a given period of time [13]. Since both the parameters are strongly dependent on climatic variables, results based on these tests may not be employed for reliable thermal performance comparison between dryers. It therefore becomes important that a test parameter that is more or less independent of climatic variables such as solar radiation intensity, ambient air temperature needs to be identified for thermal performance evaluation of solar dryer.

In view of lack of adequate information available on test method for solar dryer operating under no load condition, detailed experimental investigations on most common designs of solar dryer are needed to evolve a simple methodology that can provide reliable results. In the present study, laboratory models of forced convection mixed-mode and indirect solar dryer have been designed and constructed to perform no-load indoor experiments. It is well recognized that testing of solar equipment under indoor controlled simulation is preferred to variable outdoor climatic conditions for obtaining more reliable steady state results. In the present study, the dryers with no-load are operated with air passage between absorber plate and glass cover for the range of $300-800 \mathrm{~W} / \mathrm{m}^{2}$ and $0.009-0.026 \mathrm{~kg} / \mathrm{s}$ of absorbed thermal energy and air mass flow rate respectively under indoor simulation conditions.

\section{Proposed method for performance evaluation of solar dryer}

In order to achieve a significant, wide-spread industrial and commercial growth of dryers, it becomes essential to adopt a test method that can 
ensure reliability and durability of solar dryer technology. It is noteworthy to mention that since undue influence of moisture evaporation arising from the presence of food product is eliminated in no-load test, the results can be more consistent and accurate. In addition, the proposed test procedure should be simple in implementation and easy to understand, yet it can provide an effective tool to evaluate the thermal performance of solar dryer in a meaningful manner.

Both dryers with inlet and outlet vent open are uniformly exposed to incident solar radiation thus considered as single unit operation approximating to that of solar air collector. Based on average temperatures of absorber plate, glass cover and hot air of collector-dryer assembly, heat balance on flowing air in the passage between absorber and glass cover under steady state condition can be written as [15-16]:

$\dot{m} C_{p}\left(T_{f o}-T_{f i}\right)=A\left[h_{c p f}\left(\bar{T}_{p}-\bar{T}_{f}\right)-h_{c f g}\left(\bar{T}_{f}-\bar{T}_{g}\right)\right](1)$ where $A$ is the cross-sectional absorber area $\left(\mathrm{m}^{2}\right)$, $C_{p}$ is the specific heat of air $(J / k g K), h_{c p f}$ and $h_{c f g}$ are convective heat transfer coefficients from plate to air and from hot air to glass cover of collector-dryer assembly $\left(W / m^{2} K\right)$, respectively. $\dot{m}$ is the air mass flow rate $(\mathrm{kg} / \mathrm{s}) . \bar{T}_{p}, \bar{T}_{g}$ and $\bar{T}_{f}$ are average temperatures of absorber plate, glass cover, hot air of collector-dryer assembly $\left({ }^{\circ} \mathrm{C}\right)$, respectively. $T_{f o}$ and $T_{f i}$ are temperatures of air at the outlet and inlet of collector-dryer assembly $\left({ }^{\circ} \mathrm{C}\right)$, respectively.

In order to simplify analysis of mathematical modeling of dryer for thermal performance prediction, it is often assumed that heat transfer to air flow from absorber and to glass cover from hot air through convection is equal i.e. $h_{c p f}=h_{c f g}$ [17-19]. Eq. (1) can therefore be simplified as, assuming $h_{c p f}$ $=h_{c f g}$,

$$
\frac{\dot{m} \cdot C_{p}}{h_{c p f} \cdot A}=\frac{\left(\bar{T}_{p}-2 \bar{T}_{f}+\bar{T}_{g}\right)}{\left(T_{f o}-T_{f i}\right)}
$$

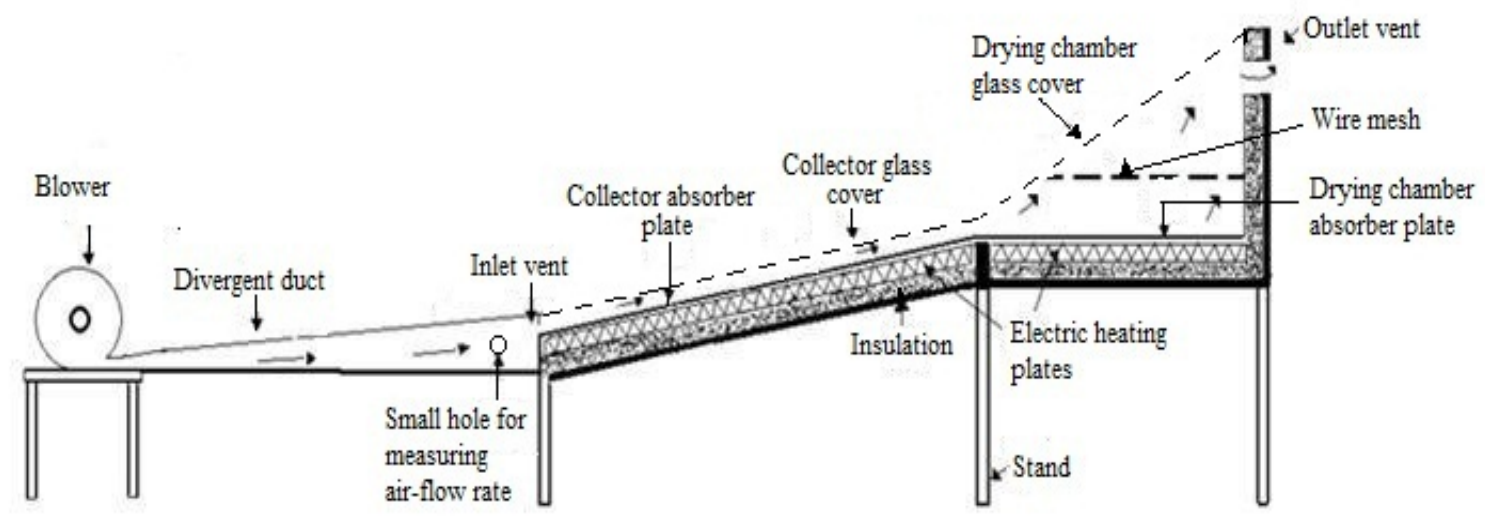

Figure 1 Schematic diagram of forced convection mixed mode solar dryer

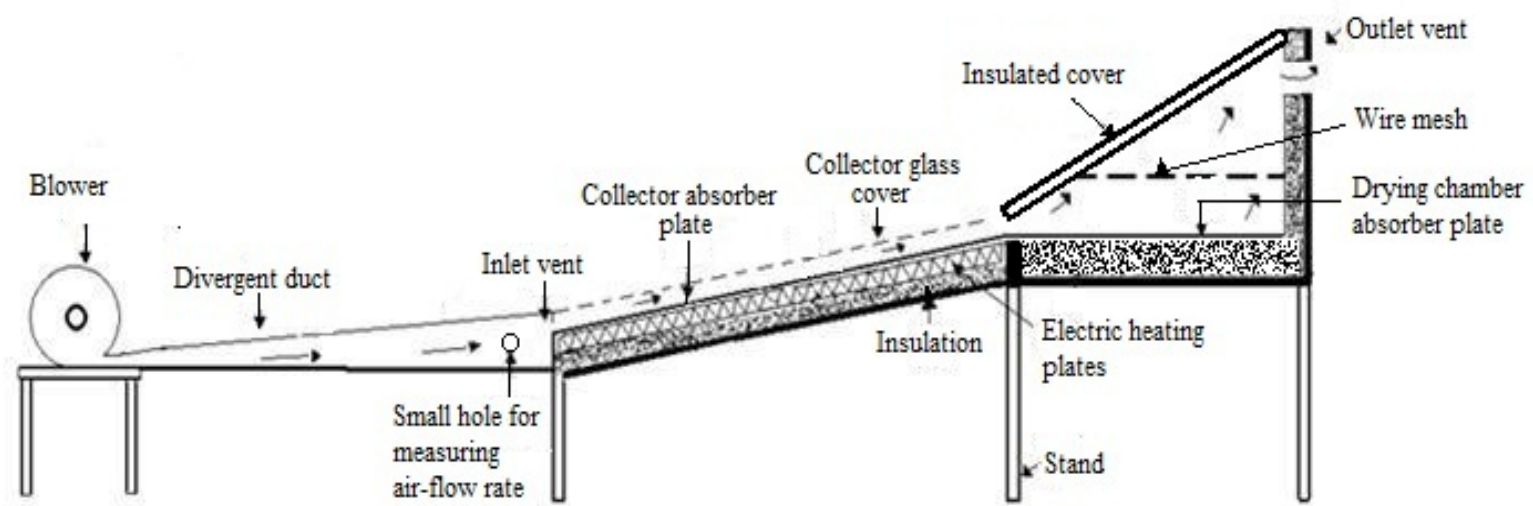

Figure 2 Schematic diagram of forced convection indirect solar dryer

The dimensionless term on the left hand side of (2) can be referred as effectiveness of dryer $(\varepsilon)$ describing the ability of an individual solar dryer to transfer heat to flowing air. It is defined as the ratio of heat capacity rate of working fluid $\left(\dot{m} . C_{p}\right)$ utilized to extract energy from the absorber surface of solar dryer system to convective heat transfer coefficient $\left(h_{c p f}\right)$ between absorber surface and 
flowing air of collector-dryer assembly. In other words, no load test describes the effectiveness of dryer characterizing various parameters namely the quality of fabrication materials in terms of heat transfer, system design comprising dimensions of dryer, air flow arrangement, dryer chimney height, inlet/outlet opening size ratio etc. It also provides the maximum hot air temperature in a dryer that can be achieved under given test conditions. It can be clearly noticed that the computation of $\varepsilon$ for a given dryer involves two important design parameters such air mass flow rate and coefficient of convective heat transfer.

\section{Experimental arrangement}

The laboratory models of mixed-mode and indirect solar dryer based forced air circulation have been constructed and tested. The mixed mode and indirect dryers have an arrangement of pre-heating the air through solar air heater. In mixed mode dryer, food product is simultaneously heated by hot air from air heater and direct exposure to solar radiation coming through a transparent cover of drying chamber. The laboratory model consisted of an inclined flat-plate solar air collector with air flowing between plate and glass cover (Fig. 1).

The collector-dryer assembly is made of matt black painted 22 gauge (0.643 $\mathrm{mm}$ thickness) aluminum sheet used as solar radiation absorber surface. In addition, on the top of solar air collector and drying chamber, individual glass cover of $4 \mathrm{~mm}$ thickness was used to allow the solar radiation inside collector-dryer assembly. Two opposite rectangular openings of size $0.45 \times 0.02 \mathrm{~m}$ at collector inlet and dryer outlet are made for air circulation. The fiber glass insulation of $0.05 \mathrm{~m}$ is provided to the bottom and sides of the dryer to minimize thermal losses through conduction. The whole assembly is encased in a thick wooden frame with an outer aluminum foil cover to protect it from weather conditions. In order to make the dryer system air leak-proof, the rubber gasket is used beneath each glass cover of air collector and drying chamber. The arrangement for wire mesh tray is also made inside the dryer chamber for keeping food product to be dried. The collectordryer assembly is supported by a mild steel angle frame.

The construction of indirect dryer is almost identical to that of mixed mode dryer with a difference in drying chamber top cover arrangement. In this dryer design, there is an opaque top cover that does not allow solar radiation to enter chamber (Fig. $2)$. Thus, food product is dried only by hot air entering from solar air heater. The fibreglass insulation pad of $0.05 \mathrm{~m}$ thickness encased in wooden ply with an outer aluminium foil was fixed on the top of drying chamber.
In order to perform indoor simulation experiments under controlled conditions, collector/dryer absorber plate is fitted with suitable number of electric heating plates. The situation of electric heating of absorber plate of dryer system resembles to symmetrical heating from solar radiation when the sun is overhead. Independent set of nine heater plates of size $0.05 \times 0.90 \mathrm{~m}$ and $0.05 \mathrm{x}$ $0.40 \mathrm{~m}$ with wattage $500 \mathrm{~W}$ and $250 \mathrm{~W}$, respectively were fitted beneath the absorber plates of air heater and drying chamber of mixed mode dryer. In indirect dryer, since drying chamber with opaque top cover does not allow solar radiation, the electric heating plates were fitted only to air heater absorber plate. In both dryers, electric heaters were designed as to provide uniform heating across the absorber plate.

To perform experiments under forced convection mode, the dryer is fitted with the electric motor $(0.5$ $\mathrm{hp}$, three phase, and $1440 \mathrm{rpm}$ ) with centrifugal fan for air circulation inside collector-dryer assembly. A divergent rectangular duct made from galvanized iron sheet of 20 gauge $(0.812 \mathrm{~mm})$ connecting the motor-fan assembly is provided at the entry of air heater to provide uniform air circulation over absorber surface. To regulate air flow rate, the frequency variable $\mathrm{AC}$ drive with adjusting knob is used.The air heated across collector plate is then fed into drying chamber. In order to measure temperature of various components of dryer namely absorber plates of air collector and dryer chamber, glass cover, hot air etc. several calibrated thermocouples have been fixed at various locations.

\section{Experimental procedure}

The series of no-load indoor experiments were performed on laboratory models of mixed mode and indirect solar dryer with inlet and outlet vents open for different operating conditions. The dryer was operated for different values absorbed thermal energy and air flow rates. A constant input electric power through servo-stabilizer (accuracy $\pm 0.5 \%$ ) was supplied to heater plates fixed to absorber surface of dryer-collector of each dryer model. The input power wattage to absorber plates of air collector and drying chamber was adjusted independently through variac so as to provide same amount of power input for a unit area of each absorber plate. (This arrangement permits to obtain simulated outdoor condition of receiving the same amount of solar radiation on absorber plates of air collector-drying chamber assembly from overhead sun). The dryer was allowed to reach a steady state condition for given power input. 
Table 1 Experimental observations for temperature of different components of mixed mode dryer operated under forced convection and results of computed effectiveness of dryer, $\varepsilon$

\begin{tabular}{|c|c|c|c|c|c|c|c|c|}
\hline \multirow{2}{*}{$\begin{array}{l}\text { Absorbed } \\
\text { thermal } \\
\text { energy } \\
\left(\mathrm{W} / \mathrm{m}^{2}\right)\end{array}$} & \multirow{2}{*}{$\begin{array}{l}\text { Ambient } \\
\text { air, } \\
T_{a m}\left({ }^{\circ} \mathrm{C}\right)\end{array}$} & \multicolumn{3}{|c|}{ Air collector } & \multicolumn{3}{|c|}{ Drying chamber } & \multirow{2}{*}{$\begin{array}{l}\text { Effectiveness of } \\
\text { Dryer, } \varepsilon \\
\text { (dimensionless ) }\end{array}$} \\
\hline & & $\begin{array}{l}\text { Plate, } \\
T_{c p}\left({ }^{\circ} \mathrm{C}\right)\end{array}$ & $\begin{array}{l}\text { Hot air, } \\
T_{c f}\left({ }^{\circ} \mathrm{C}\right)\end{array}$ & $\begin{array}{l}\text { Glass cover, } \\
T_{c g}\left({ }^{\circ} \mathrm{C}\right)\end{array}$ & $\begin{array}{l}\text { Plate, } \\
T_{d p}\left({ }^{\circ} \mathrm{C}\right)\end{array}$ & $\begin{array}{l}\text { Hot air, } \\
T_{d f}\left({ }^{\circ} \mathrm{C}\right)\end{array}$ & $\begin{array}{l}\text { Glass } \\
\text { cover, } \\
T_{d g}\left({ }^{\circ} \mathrm{C}\right)\end{array}$ & \\
\hline
\end{tabular}

$\begin{array}{crr}\text { 1) } & \text { Mass flow rate: } 0.009 \mathrm{~kg} / \mathrm{s} \\ 250 & 33.01 & 54.89 \\ 300 & 33.01 & 56.6 \\ 450 & 31.05 & 61.49 \\ 600 & 31.79 & 72.2 \\ 750 & 31.05 & 77.8 \\ 800 & 32.27 & 81.3\end{array}$

5.89
6.60
7.49
72.25
7.87
81.30

38.75
39.73
41.93
46.33
46.70
49.02

37.65
38.88
40.10
42.30
43.64
44.01

59.41
62.59
73.11
84.60
93.40
99.51

45.97
46.94
48.90
55.01
58.68
62.35

$\begin{array}{ll}41.08 & 0.91 \\ 42.05 & 0.96 \\ 44.74 & 1.06 \\ 48.90 & 0.98 \\ 51.10 & 1.00 \\ 53.06 & 0.92\end{array}$

2) Mass flow rate: $0.017 \mathrm{~kg} / \mathrm{s}$

$\begin{array}{lll}300 & 32.76 & 54.40 \\ 450 & 33.74 & 57.46 \\ 600 & 32.52 & 62.35 \\ 750 & 33.50 & 67.97 \\ 800 & 34.72 & 70.66\end{array}$

$\mathrm{kg} / \mathrm{s}$
57.40
57.46

$36.31 \quad 34.72$

$37.65 \quad 36.92$

$39.24 \quad 37.90$

$41.20 \quad 39.24$

$42.42 \quad 40.71$

3) Mass flow rate: $0.026 \mathrm{~kg} / \mathrm{s}$

$\begin{array}{lll}250 & 29.34 & 40.83 \\ 300 & 33.01 & 44.62 \\ 450 & 32.27 & 51.83 \\ 600 & 31.30 & 57.34 \\ 750 & 32.76 & 61.25 \\ 800 & 34.47 & 65.40\end{array}$

$\begin{array}{ll}31.91 & 30.93 \\ 34.47 & 33.01 \\ 35.45 & 33.99 \\ 36.68 & 35.09 \\ 38.63 & 36.19 \\ 40.46 & 39.98\end{array}$

51.35
64.30
69.44
76.77
80.93



45.97
52.57
55.01
59.66
66.99
70.42

$\begin{array}{lll}42.05 & 38.88 & 1.22 \\ 46.46 & 41.57 & 1.26 \\ 47.19 & 42.30 & 1.33 \\ 50.61 & 45.23 & 1.33 \\ 53.79 & 46.46 & 1.21\end{array}$

The experiments were performed over a wide The experiments were performed over a wide range of power input supplied to dryer/collector absorber plate. Each data point was finalized in 4 to 6 hours to get a very good steady state. The steady state conditions are defined as a 10 minutes period when the variation in the temperature of dryer components and ambient temperature is $\pm 1.0^{\circ} \mathrm{C}$ and $\pm 0.2^{\circ} \mathrm{C}$, respectively [4]. On reaching steady-state condition, temperatures of various components of air collector and dryer along with ambient air were measured. The temperatures of various components of collectordryer assembly were measured by pre-calibrated chrome-alumel thermocouples connected to microvoltmeter (accuracy $\pm 0.1{ }^{\circ} \mathrm{C}$ ). Six thermocouples (two each on absorber, glass cover and air passage) and four thermocouples (one each on plate, top cover and two in air passage) were fixed inside air collector appreciation of temperature measurement. The average temperatures of absorber plate, glass cover and hot air of collector-dryer assembly are computed from measured individual temperature data of each component of solar air collector and dryer chamber respectively. One additional thermocouple was used to measure ambient air temperature. The power input to electric heater plates was measured by calibrated digital wattmeter (accuracy $\pm 1.0 \%$ ). The portable air velocity transmitter (Lufft, Germany) operated with power supply of $24 \mathrm{VAC} / \mathrm{DC}$ was used to measure the air flow rate at the inlet of solar collector-dryer assembly by inserting the probe inside a small opening made in duct (accuracy within $\pm 0.2 \mathrm{~m} / \mathrm{s}$ ). Several experiments were performed on mixedmode and indirect solar dryers for a wide range of power input varying from 300 to $800 \mathrm{~W} / \mathrm{m}^{2}$ of dryer/collector absorber plate and air mass flow rate range of 0.009 to $0.026 \mathrm{~kg} / \mathrm{s}$. to study influence of these parameters on dryer performance. The experimental observations of mixed mode and indirect dryers for various test runs are presented in Tables 1 and 2, respectively.

\section{Statistical analysis}

In order to find out consistencies in experimental results of $\varepsilon$ for each dryer design and interpret them in a rational manner, a statistical analysis has been undertaken. The parameters used in the study are defined as [20]: 
Table 2. Experimental observations for temperature of different components of indirect dryer operated under forced convection and results of computed effectiveness of dryer, $\varepsilon$

\begin{tabular}{|c|c|c|c|c|c|c|c|c|}
\hline \multirow{2}{*}{$\begin{array}{l}\text { Absorbed } \\
\text { thermal } \\
\text { energy } \\
\left(\mathrm{W} / \mathrm{m}^{2}\right)\end{array}$} & \multirow{2}{*}{$\begin{array}{l}\text { Ambient } \\
\text { air, } \\
T_{a m}\left({ }^{\circ} \mathrm{C}\right)\end{array}$} & \multicolumn{3}{|c|}{ Air collector } & \multicolumn{3}{|c|}{ Drying chamber } & \multirow{2}{*}{$\begin{array}{l}\text { Effectiveness of } \\
\text { Dryer, } \varepsilon \\
\text { (dimensionless ) }\end{array}$} \\
\hline & & $\begin{array}{l}\text { Plate, } \\
T_{c p}\left({ }^{\circ} \mathrm{C}\right)\end{array}$ & $\begin{array}{l}\text { Hot air, } \\
T_{c f}\left({ }^{\circ} \mathrm{C}\right)\end{array}$ & $\begin{array}{l}\text { Glass cover, } \\
T_{c g}\left({ }^{\circ} \mathrm{C}\right)\end{array}$ & $\begin{array}{l}\text { Plate, } \\
T_{d p}\left({ }^{\circ} \mathrm{C}\right)\end{array}$ & $\begin{array}{l}\text { Hot air, } \\
T_{d f}\left({ }^{\circ} \mathrm{C}\right)\end{array}$ & $\begin{array}{l}\text { Insulated } \\
\text { cover, } \\
T_{d i}\left({ }^{\circ} \mathrm{C}\right) \\
\end{array}$ & \\
\hline
\end{tabular}

\begin{tabular}{|c|c|c|}
\hline 1) & Mass flow rat & $7 \mathrm{~kg} / \mathrm{s}$ \\
\hline 300 & 29.34 & 54.16 \\
\hline 450 & 30.07 & 62.47 \\
\hline 600 & 30.07 & 69.07 \\
\hline 750 & 29.34 & 75.06 \\
\hline 800 & 30.07 & 78.73 \\
\hline
\end{tabular}

36.43
38.26
39.85
40.71
42.54

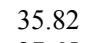

37.65

38.88

40.10

41.69

2) Mass flow rate: $0.017 \mathrm{~kg} / \mathrm{s}$

$\begin{array}{lll}300 & 28.85 & 47.19 \\ 450 & 28.61 & 52.32 \\ 600 & 28.61 & 57.95 \\ 750 & 29.58 & 63.9 \\ 810 & 30.81 & 65.6\end{array}$

3) Mass flow rate: $0.026 \mathrm{~kg} / \mathrm{s}$

$\begin{array}{lll}300 & 27.63 & 43.15 \\ 450 & 26.90 & 48.45 \\ 600 & 27.87 & 51.96 \\ 750 & 27.87 & 55.50 \\ 800 & 30.07 & 59.78\end{array}$

\subsection{Arithmetic mean $(\overline{\mathbf{x}})$}

Arithmetic mean of a given set of observations is their sum divided by the number of observations. It can be expressed as:

$\bar{x}=\frac{\sum_{i=1}^{n} x_{i}}{N}$

where $x_{i}$ represents the value obtained in the $i^{\text {th }}$ test result and $\mathrm{N}$ is the total number of observations.

\subsection{Standard deviation $(\sigma)$}

Standard deviation is defined as the positive square root of the arithmetic mean of the squares of the deviations of given observations from their arithmetic mean. It may be expressed as:

$\sigma=\sqrt{\frac{1}{(N-1)} \sum\left(x_{i}-\bar{x}\right)^{2}}$

The magnitude of the standard deviation essentially reflects on the scatter from the mean. If the $\sigma$ is small, that means that scatter in the data is small and consequently more values are concentrated near the mean value.

\subsection{Standard error of mean (SE)}

Standard error of the mean represents the extent of random error in the measured values and is defined as the ratio of the standard deviation and the square root of the number of values in any given set of condition i.e.
$S E=\frac{\sigma}{\sqrt{N}}$

\subsection{Confidence interval (E)}

The interval within which the actual value of the parameter is expected to lie with a certain probability is known as the confidence interval and the two limits are called confidence limits. Instead of a single estimate for the mean, a confidence interval generates a lower and upper limit for the mean. The interval estimate gives an indication of how much uncertainty there is in our estimate of the true mean.

The narrower the interval, the more precise is our estimate. The 95\%, confidence interval can be expressed as:

$\bar{x}-1.96\left[\frac{\sigma}{\sqrt{N}}\right] \leq E \leq \bar{x}+1.96\left[\frac{\sigma}{\sqrt{N}}\right]$

\section{Results and discussion}

In the present study, mixed-mode and indirect solar dryer are chosen for indoor experimental investigation. Table 1 and 2 represents the average temperature data of various components of mixedmode and indirect dryer respectively, operated under absorbed energy range of $300-800 \mathrm{~W} / \mathrm{m}^{2}$ forced air circulation. Dryer effectiveness, $\varepsilon$ values for no load condition have been calculated from (2) using the 
Table 3 Results of statistical analysis for effectiveness of dryer $\varepsilon$ for mixed-mode and indirect solar dryer

\begin{tabular}{|c|c|c|c|c|c|c|}
\hline \multirow{2}{*}{$\begin{array}{l}\text { Air mass } \\
\text { flow rate } \\
(\mathrm{kg} / \mathrm{s})\end{array}$} & \multicolumn{3}{|c|}{ Mixed-mode dryer } & \multicolumn{3}{|c|}{ Indirect dryer } \\
\hline & $\begin{array}{l}\text { Standard } \\
\text { deviation, }(\sigma)\end{array}$ & $\begin{array}{l}\text { Standard error } \\
\text { of mean, (SE) }\end{array}$ & $\begin{array}{l}95 \% \text { Confidence } \\
\text { interval }\end{array}$ & $\begin{array}{l}\text { Standard } \\
\text { deviation, }(\sigma)\end{array}$ & $\begin{array}{l}\text { Standard error } \\
\text { of mean, (SE) }\end{array}$ & $\begin{array}{l}95 \% \text { Confidence } \\
\text { interval }\end{array}$ \\
\hline 0.009 & 0.048 & 0.019 & $0.932<0.970<1.009$ & 0.043 & 0.019 & $0.408<0.446<0.484$ \\
\hline 0.017 & 0.059 & 0.026 & $1.219<1.271<1.323$ & 0.072 & 0.032 & $0.825<0.888<0.952$ \\
\hline 0.026 & 0.084 & 0.034 & $1.256<1.324<1.392$ & 0.016 & 0.007 & $1.048<1.061<1.075$ \\
\hline
\end{tabular}

average temperature data. The analysis of results indicates that the mean $\varepsilon$ values of mixed mode dryer are found to be $0.97,1.27$ and 1.32 for air mass flow rates of $0.009,0.017$ and $0.026 \mathrm{~kg} / \mathrm{s}$, respectively. On the other hand, these figures are $0.45,0.89$ and 1.06 for indirect dryer. Fig. 3 shows the comparison of experimental mean $\varepsilon$ values under different air mass flow rates for mixed-mode and indirect dryer, respectively. As can be seen, there is marked improvement in $\varepsilon$ values as the flow rate increases from 0.009 to $0.026 \mathrm{~kg} / \mathrm{s}$. This is due to the fact that heat transfer coefficient, $h_{c p f}$ also increases with air flow rate. In addition, mixed-mode dryer shows higher values of $\varepsilon$ as compared to indirect dryer. For instance, when mass flow rate changes from 0.009 to $0.017 \mathrm{~kg} / \mathrm{s}$ substantial improvement of $31 \%$ and $98 \%$ in mean $\varepsilon$ value for a given range of absorbed thermal energy is achieved for mixed-mode and indirect dryer, respectively. However, this improvement in mean $\varepsilon$ value gradually reduces to $4 \%$ and $19 \%$ as the mass flow rate augments from 0.017 and $0.026 \mathrm{~kg} / \mathrm{s}$ for mixed-mode and indirect dryer, respectively. Therefore, the importance of selecting a suitable value for the mass flow rate arises, so that optimum values of $\varepsilon$ with minimum cost can be achieved for satisfactory operation of dryer system.

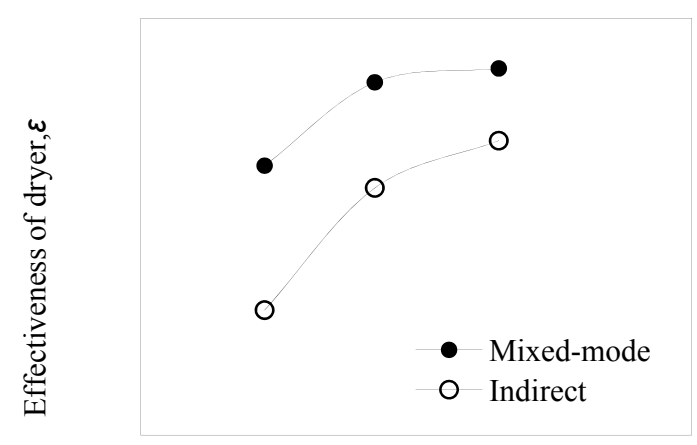

Air mass flow rate $(\mathrm{kg} / \mathrm{sec})$

Figure 3 Comparative study of air circulation effect on $\varepsilon$ of mixed-mode and indirect dryer
Table 3 illustrates the results of statistical analysis. It can be noticed that the low values of standard error of mean have been obtained for both dryers. The standard error of mean in $\varepsilon$ for mixed-mode and indirect dryer is found to be in range of $0.019-0.034$ and $0.007-0.034$ for air flow range of 0.009-0.026 $\mathrm{kg} / \mathrm{s}$, respectively. These results are indicative of good consistency of $\varepsilon$ values with small amount of scattering for a wide range of absorbed energy levels $\left(300-800 \mathrm{~W} / \mathrm{m}^{2}\right)$ and ambient air temperatures (24$\left.34^{\circ} \mathrm{C}\right)$.

Further, the estimation results of $95 \%$ confidence interval of experimental $\varepsilon$ indicate insignificant variation of extreme $\varepsilon$ values about the mean for dryers operated under different test conditions. Since this dimensionless parameter $\varepsilon$ is found to be more or less independent of climatic variables, it can satisfactorily be used as a performance index for comparison of solar dryers on equitable basis.

\section{Conclusion}

In the present investigation, simple thermal performance evaluation method for solar dryer rating is proposed. Based on proposed methodology, the dimensionless parameter referred as effectiveness of dryer, $\varepsilon$ that is more or less independent of climatic variables namely absorbed thermal energy and ambient air temperature is identified. The study also reveals that for a given absorbed energy, mixedmode in comparison to indirect dryer performs better in terms of higher values in $\varepsilon$. The results of statistical analysis reveal that fairly consistent values of $\varepsilon$ are obtained for each solar dryer tested irrespective of change in process variables investigated. This important finding of present study facilitates performance comparison between different solar dryer designs on equitable basis and would essentially help the policy makers, research institutions and industries in ensuring reliable and durable solar dryer systems and eventually assist the end users in appropriate selection. 


\section{References}

[1] M.A. Leon, S. Kumar and S.C. Bhattacharya,"A comprehensive procedure for performance evaluation of solar food dryers," Renewable and Sustainable Energy vol. 6, pp. 367-393, 2002.

[2] O.V. Ekechukwe, B. Norton, "Review of solar energy drying systems II: an overview of solar drying technology," Energy Conversion and Management, vol. 40,pp. 616-55, 1999.

[3] M.S. Sodha and Chandra Ram, "Solar drying systems and their testing procedures: a review," Energy Conversion and Management, vol. 35(3),pp. 219-67, 1994.

[4] L. M. Diamante, P.A. Munro, "Mathematical modelling of the thin layer solar drying of sweet potato slices," Solar Energy, vol. 51, pp. 271276, 1993.

[5] ASHRAE Standard 93-1986, "Method of testing to determine the thermal performance of solar collectors," American Society for Heating, Refrigerating and Airconditioning Engineers, Atlanta (USA), 1986.

[6] IS 13429-2000, "Solar cooker-Box type specification-part 3: Test Method," Bureau of Indian Standards, New Delhi (India), 2000.

[7] Grupp M., Bergler., O. Maria and G. Schroder , "Comparative tests of solar dryers," Technology Demonstration Center (TDC) Serial Report 2/95, Plataforma Solar de Almeria (PSA), Spain, 1995.

[8] Y. Jannot and Y. Coulibaly, "The evaporative capacity as a performance index for a solar drier-air heater", Solar Energy, vol. 63(6), pp. 387-91, 1998.

[9] P.C. Pande and K.P. Thanvi, "Design and development of a solar dryer cum water heater," Energy conversion and Management, vol. 31 (5), pp. 419-424, 1991.

[10] B. Bena and R.J. Fuller,"Natural convection solar dryer with biomass back-up heater," Solar Energy, vol. 72(1), pp. 75-83, 2002.
[11] A.A. El-Sebaii, S. Aboul-Enein, M.R.I. Ramadan and H.G. El-Gohary, "Experimental investigation of an indirect type natural convection solar dryer," Energy Conversion and Management, vol. 43 (16), pp. 2251-2266, 2002.

[12] F.K. Forson, M.A.A. Nazha and H. Rajakaruna,"Modeling and experimental studies on a mixed-mode natural convection solar crop dryer,"Solar Energy, vol. 81 (3), pp. 346-357, 2007.

[13] P. P. Singh, S. Singh, S.S. Dhaliwal, "Multishelf domestic solar dryer," Energy Conversion and Management, vol. 47, pp. 1799-1815, 2006.

[14] A. Sreekumar, P. E. Manikantan, K. P. Vijayakuma, "Performance of indirect solar cabinet dryer," Energy Conversion and Management, vol. 49, pp. 1388-1395, 2008.

[15] J.A.Duffie and W.A.Beckman, "Thermal engineering of thermal processes," John Wiley \& Sons, New York, 1991.

[16] G.N. Tiwari, "Solar energy fundamentals, design, modeling and application," Narosa publishing house, New Delhi, 2002.

[17] I.N. Simate, "Optimization of mixed-mode and indirect-mode natural convection solar dryers." Renewable Energy, vol. 28, pp. 435-453,2003.

[18] B. K. Balaand J. L. Woods, "Simulation of the Indirect Natural Convection Solar Drying of Rough Rice," Solar Energy, Vol. 53(3), pp-259266,1994.

[19] S.Youcef-Ali and J.Y. Desmons, "Influence of the aerothermic parameters and theproduct quantity on the production capacity of anindirect solar dryer," Renewable Energy, vol. 32, pp. 496-511, 2007.

[20] J. P. Holman, "Experimental Methods for Engineers," Tata McGraw-Hill, New Delhi (India), 2008. 